\title{
A "NEW" DISCOURSE ABOUT HIGHER EDUCATION IN BRAZIL KNOWLEDGE SOCIETY OR KNOWLEDGE ECONOMY?
}

\author{
SOARES A. M., VELLOSO, A.; LANNES, D. \\ Instituto de Bioquímica Médica, Universidade Federal do Rio de Janeiro, \\ Rio de Janeiro - RJ - Brasil
}

In the last twenty years, the knowledge producer's discourses were "contagious" by distinct ideas about the end of the modern capitalism age. Actually, a new discourse can be identified among the university leaderships of the Brazilian governmental Higher Education institutions. This study intends to identify the ideological aspects in the president of universities discourses. This position probably would be lead the academic production. A total of 27 university presidents discourses (signed articles) were collected and at least, 16 texts were analyzed. The "Discourse of the Collective Subject" (DSC) of these leader was divided in four topics: (1) University, (2) Education, (3) Research and (4) Extension. In the topic 1 were identified five "Central-Ideas": - University fragility; University transforming function; Autonomy; Funding; and Politics Organization. In the topic 2, two Cls were identified: Generalist and global formation and Education is not a commodity. Two Cls were also identified in the topic 3: The role of the Research; and Graduation does not enable to the research. In the topic 4, one Cl appeared: Share knowledge. The preliminary data indicates differences in the leader's discourses about the Higher Education function. However, the data suggest a trend to assume the knowledge as an economic product instead of social production.

Keywords: Discourse of the Collective Subject, University leaders 